\title{
Tourism in Kashmir Valley: Problems and Prospects
}

\author{
Altaf Ahmad Kumar \\ Research Scholar Department of Economics, Central University of Kashmir, Jammu and Kashmir, India \\ E-Mail: altafqumar15@gmail.com
}

\begin{abstract}
Kashmir valley has continued to be an internationally commended tourist destination. Every year a huge number of tourists from all parts of the world visit the tourist spots of J\&K. Tourism sector contributes about $6.98 \%$ to the state gross domestic product. The main objectives of the present Study are to examine the trend of tourist inflow in Kashmir valley from 1975-2015 and highlight some multifarious problems, which are to be taken into consideration as soon as possible in order to boost tourist arrival in the Kashmir valley. In consideration with these objectives, this paper involved mainly the data from secondary sources available on the subject. Various descriptive statistical measures have been used to find the averages and median positions of tourist expenditure pattern during their stay in the valley. This study found that both foreign and domestic tourist arrival showed a continuously declining trend from 1990 till 1997 for Kashmir witnessed worst years of its history due to internal disturbances. However, post-1997, tourist arrival to Kashmir Valley showed an increasing trend up to 2013 due to frequent political developments but the tourist arrival suddenly decreased once again due to uncertainty and disturbances. It is revealed from the findings that the Kashmir valley, despite its attractive scenic beauty, is lagging behind in terms of annual foreign tourist arrivals to the state itself and the country as a whole when compared with Ladakh.
\end{abstract}

Keywords: Tourist Inflow, Trend, Share and Problems

\section{INTRODUCTION}

Kashmir is known for its beauty, hospitality, and unity in diversity and offers something to everyone. The rich beauty of its attractions, temperate climate, ancient monuments, its grandeur snow crowded mountains, its green forests and grasslands, its quiet backwaters and beaches, its beautiful rivers and lakes, and above all its well-meaning, charming people- these are a few of the countless facets of Kashmir valley which are timeless in their appeal. All these go to make Kashmir Valley a "land of paradise on earth". Kashmir valley has continued an internationally commended tourist destination, every year lot of tourists from all parts of the world are visiting the tourist spots of Kashmir valley (Rai, R. A. 2007, Nengroo.A.H 2014). With the emerging competition from neighboring states that have other means of economic development that could improve their economies, Jammu and Kashmir economy particularly valley's economy highly dependent on agriculture and allied sector. About $70 \%$ of the population of the state depends directly on this sector for their livelihood product (JK economic survey 2014-15). There is no doubt that Government services and some small-scale manufacturing units are the major sectors in the valley's economy, as the government is currently working towards inclusive growth and development in which tourism can play an important role. It contributes about $6.98 \%$ of state gross domestic product (JK economic survey 2017). However, in order to encourage tourists and investment into the valley, the tourism industry, like any other industry, needs inclusive planning and management for promoting inclusive growth and development of the state economy. The planning process could be made more effective if the most multifarious problems related to tourism industry were identified. Information of these problems can provide policymakers with useful guidelines for planning the development of tourist products and programmes to meet the requirements of tourists.

\section{OBJECTIVES OF THE STUDY}

1. To Examine the trend of tourist inflow of Kashmir valley from 1975-2015.

2. To highlight some multifarious problems that can provide policymakers with useful guidelines for planning the development of tourist products and programmes to meet the requirements of tourists.

\section{RESEARCH METHODOLOGY}

In consideration with the above objectives, this paper involved mainly the data from secondary sources, collected from various organizations like Ministry of Tourism-GOI, Jammu and Kashmir Tourism Development Corporation and Directorate of Tourism (Jammu/Kashmir). In addition to this, data have also been collected from other reliable sources like articles, journals, and newspapers available on the subject. Various descriptive statistical measures have been used to find the averages and median positions of tourist expenditure pattern during their stay in the valley.

The trend of tourist arrivals in Kashmir Figure 1and 2 shows the trend of tourist arrivals to the valley from 1975 to 2015. The trend of tourist arrivals to the valley from 1975 to 2015 indicates that the tourist arrivals shows an upward trend up to 1983 and decreases in 1984. In 1985, after tourism was described as an industry by the government of India both domestic and foreign tourist arrivals increase intensely up to 1989. In 1985 domestic tourist arrival increases with a growth rate of 141.64 percentage points, foreign tourist arrival increases with a growth rate of $4.2 \%$ and total tourist arrival increases with a growth rate of 119.79 percentage points. After 1989 tourist arrival 
decreases sharply and was even close to zero in 1990-1997. During these eight years, Kashmir was transformed from a tourist destination to terrorist destination. Total tourist arrival in Kashmir Valley increases dramatically from 16138 in 1997 to 109883 in 1998 and 217292 in 1999. Domestic tourist arrivals increase from 7027 in 1997 to 99636 in 1998 and 200162 in 1999 . It also shows that the foreign tourist arrivals increased from 9111 in 1997 to 10247 in 1998 and 17130 in 1999 with a growth rate of $12.46 \%$ and $67.17 \%$ respectively. After 1999 tourist arrival again decreased due political insurgency, uncertainty and human killings which had crippled the life in the Valley of Kashmir. After 1999 there was a bloodbath in Kashmir Valley. Eight blasts were heard in Jammu on republic day in 2000, 35 Sikhs were massacred in Anantnag on 21 March 2000 and 23 people were killed on 10 April 2000, migration of Sikhs from Valley begins, killing of Amaranth pilgrims on August 2000 and the dead body of German tourist was recovered by Kashmir police, Kargil war etc. are major causes of decline in tourist inflow in Kashmir valley during this decade. Foreign tourist arrival again shows an upward trend up to 2013 .

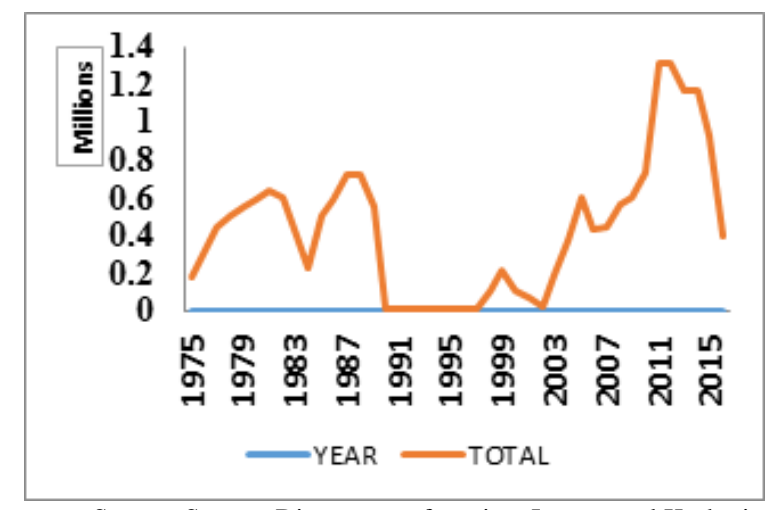

Source: Source: Directorate of tourism Jammu and Kashmir

Fig. 1 Trend of total tourist arrival from $1975-2015$

Foreign tourist arrival again shows an upward trend up to 2013. In 2014 there was a flood in Kashmir valley which badly hit the tourist arrivals and tourist infrastructure in Kashmir valley. A tourist arrival in Kashmir valley showed a decreasing trend in 2015-2016 because of uncertainty in Kashmir valley from last two years.

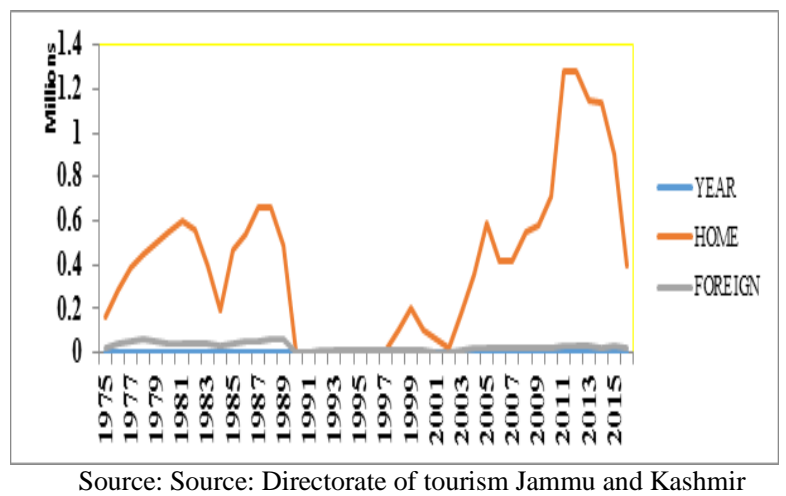

Fig. 2 Trend of domestic and foreign tourist arrival from 1975-2015
TABLE I SHARE OF KASHMIR VALLEY AND LADAKH IN INDIAN FTAS

\begin{tabular}{|c|c|c|c|c|c|}
\hline Year & $\begin{array}{c}\text { FTA in } \\
\text { India }\end{array}$ & $\begin{array}{c}\text { FTA In } \\
\text { Kashmir }\end{array}$ & $\begin{array}{c}\% \\
\text { Share }\end{array}$ & $\begin{array}{c}\text { FT in } \\
\text { Ladakh }\end{array}$ & $\begin{array}{c}\% \\
\text { Share }\end{array}$ \\
\hline 2006 & 4447167 & 20009 & 0.44 & 26078 & 0.59 \\
\hline 2007 & 5081504 & 24576 & 0.48 & 28178 & 0.55 \\
\hline 2008 & 5282603 & 21588 & 0.41 & 38936 & 0.73 \\
\hline 2009 & 5167699 & 23904 & 0.46 & 30570 & 0.59 \\
\hline 2010 & 5775692 & 25984 & 0.44 & 22115 & 0.38 \\
\hline 2011 & 6309222 & 32110 & 0.51 & 36662 & 0.58 \\
\hline 2012 & 6577745 & 37166 & 0.56 & 38510 & 0.58 \\
\hline 2013 & 6967601 & 29143 & 0.42 & 31143 & 0.44 \\
\hline 2014 & 7679099 & 27172 & 0.35 & 59305 & 0.77 \\
\hline 2015 & 8027133 & 28954 & 0.36 & 29614 & 0.37 \\
\hline 2016 & 8804411 & 24516 & 0.27 & 38005 & 0.43 \\
\hline \multicolumn{5}{|c|}{ Source: Directorate of tourism Jammu and Kashmir }
\end{tabular}

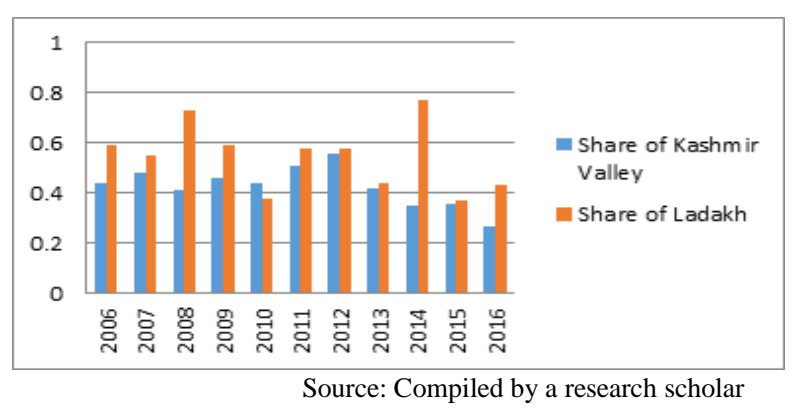

Fig. 3 Share of Kashmir valley and Ladakh in Indian FTAs

Table I shows that the share of Kashmir valley in total foreign tourist arrivals of the country is negligible as compared to Ladakh. Foreign tourist arrivals of India increased from 4447167 in 2006 to 8804411 in 2016. Foreign tourist arrivals in Kashmir Valley fluctuates and was highest in 2012 as the foreign tourist arrival increased from 32110 in 2011 to 37166 in 2012 with a percentage share of $0.56 \%$ and lowest in 2016 with a percentage share of $0.27 \%$ in total tourist arrivals of the country. It also shows that the share of Ladakh in total foreign tourist arrivals of the country was highest in the year 2014 with a percentage share of $0.77 \%$ and lowest in the year of 2015 with a percentage share of $0.37 \%$. Figure 3 shows the percentage share of tourist arrivals of Kashmir and Ladakh from the foreign tourist arrival of India. It indicates that the share of Ladakh is highest in the total tourist arrival of the country than Kashmir Valley. Table II shows that the share of Kashmir valley in total foreign tourist arrivals of the state is negligible as compared to Ladakh. The share of Valley from foreign tourist arrivals was highest in the year 2010 and lowest in the year of 2014. The foreign tourist arrival in J\&K increases from 46087 in 2006 to 55000 in 2008. Foreign tourist arrival in J\&K was highest in the year 2014 and lowest in 2006. Foreign tourist arrivals in Kashmir Valley fluctuates and was highest in 2012 as the foreign tourist arrivals increased from 32110 to 37166 with $47.16 \%$ share from the total foreign tourist arrivals of the State. The share of Kashmir valley from the total foreign tourist arrival of the state was highest in 2010 with a percentage share of 
$54.02 \%$ and lowest in 2014 with a percentage share of $41.42 \%$. It was also observed that the foreign tourist arrivals in Ladakh fluctuates in this decade and was highest in 2014 as the foreign tourist arrivals in Ladakh increased from 31143 in 2013 to 59305 in 2014 with a percentage share of $51.12 \%$ and $68.58 \%$. The share of Ladakh in J\&K foreign tourist arrival was highest in 2008 with a percentage share of 70.80 and lowest in 2010 with $45.98 \%$. Figure 3 shows the percentage share of Kashmir and Ladakh from the total foreign tourist arrivals of the state from 2006-2016. Both the table and the figure indicates that the share of Ladakh in total tourist arrival of the state is highest than Kashmir valley.

TABLE II THE SHARE OF KASHMIR VALLEY AND LADAKH IN TOTAL FTAS

\begin{tabular}{|c|c|c|c|c|c|}
\hline Year & $\begin{array}{c}\text { FTA in } \\
\text { J\&K }\end{array}$ & $\begin{array}{c}\text { FTA in } \\
\text { Kashmir }\end{array}$ & \%Share & $\begin{array}{c}\text { FTA in } \\
\text { Ladakh }\end{array}$ & \%Share \\
\hline 2006 & 46087 & 20009 & 43.41 & 26078 & 56.59 \\
\hline 2007 & 53053 & 24576 & 46.32 & 28178 & 53.12 \\
\hline 2008 & 55000 & 21588 & 39.25 & 38936 & 70.80 \\
\hline 2009 & 54475 & 23904 & 43.88 & 30570 & 56.12 \\
\hline 2010 & 48099 & 25984 & 54.02 & 22115 & 45.98 \\
\hline 2011 & 71593 & 32110 & 44.85 & 36662 & 51.21 \\
\hline 2012 & 78802 & 37166 & 47.16 & 38510 & 48.87 \\
\hline 2013 & 60845 & 29143 & 47.89 & 31143 & 51.12 \\
\hline 2014 & 86477 & 27172 & 31.42 & 59305 & 68.58 \\
\hline 2015 & 58568 & 28954 & 49.43 & 29614 & 50.56 \\
\hline 2016 & 63207 & 24516 & 38.78 & 38005 & 60.13 \\
\hline
\end{tabular}

Source: Directorate of tourism Jammu and Kashmir \& MOT, India
Table III shows that the average of total foreign tourist arrivals from 2006-2016 was found to be 6374534.18, 26829.27 and 34465.09 in India, Kashmir Valley and in Ladakh respectively. Ladakh has more share from the total foreign tourist arrivals in the country than the Kashmir Valley. Ladakh has $0.32 \%$ more share in total tourist arrivals of the country than Kashmir Valley in 2008 and has $0.42 \%$ in 2014 and $0.16 \%$ in 2016 more FTA flow than Kashmir valley. It also shows that on an average Ladakh has $0.12 \%$ more share in the country than Kashmir Valley. The standard deviation of tourist arrivals in The Valley has been found to be lowest as compared to foreign tourist arrivals to Ladakh. Thus, it could be concluded from the analysis that the FTAs in Ladakh is stronger over a period under study compared to foreign tourist arrivals in Kashmir valley.

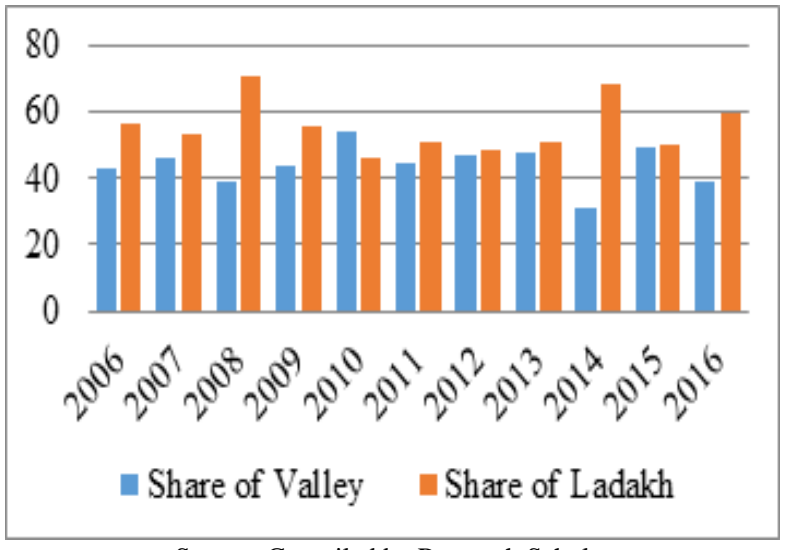

Source: Compiled by Research Scholar

Fig. 4 Share of Kashmir valley and Ladakh in total FTAs of J\&K

TABLE III DESCRIPTIVE STATISTICS OF A SHARE OF TOURIST ARRIVALS FROM INDIA

\begin{tabular}{|l|c|c|c|c|}
\hline \multicolumn{1}{|c|}{ Tourist arrival } & N & Minimum & Maximum & Mean \\
\hline Foreign Tourist Arrivals in India & 11 & 4447167.00 & 8804411.00 & 6374534.18 \\
\hline Foreign Tourist Arrivals in Kashmir & 11 & 20009.00 & 37166.00 & 26829.27 \\
\hline Foreign Tourist Arrivals in Ladakh & 11 & 22115.00 & 59305.00 & 34465.09 \\
\hline \%Share of Kashmir & 11 & .27 & .56 & .42 \\
\hline \% Share of Ladakh & 11 & .37 & .77 & .54 \\
\hline
\end{tabular}

TABLE IV DESCRIPTIVE STATISTICS OF A SHARE OF TOURIST ARRIVALS FROM J\&K

\begin{tabular}{|l|c|c|c|c|}
\hline \multicolumn{1}{|c|}{ Tourist arrival } & N & Minimum & Maximum & Mean \\
\hline Foreign Tourist Arrival in J\&K & 11 & 46087.00 & 86477.00 & 61473.27 \\
\hline Foreign Tourist Arrivals in Kashmir & 11 & 20009.00 & 37166.00 & 26829.27 \\
\hline Foreign Tourist Arrivals in Ladakh & 11 & 22115.00 & 59305.00 & 34465.09 \\
\hline \% share of Kashmir & 11 & 31.42 & 54.02 & 44.22 \\
\hline \% share of Ladakh & 11 & 46.0 & 70.8 & 55.73 \\
\hline
\end{tabular}

Table IV shows that the average of total foreign tourist arrivals from 2006-2016 was found to be 61473.27, 26829.27 and 34465.09 in India, Kashmir Valley and in Ladakh respectively. Ladakh has more shares from the total foreign tourist arrivals of the state than the Kashmir Valley.
Ladakh has $37.16 \%$ more share in total tourist arrivals of the state than Kashmir Valley in 2014 and has 49\% in 2015 and $40 \%$ in 2016 more share than Kashmir valley. It shows that on an average Ladakh has $11.52 \%$ more share in the state than Kashmir Valley. The standard deviation of tourist 
arrivals in The Valley has been found to be lowest as compared to foreign tourist arrivals to Ladakh. Thus, it could be concluded from the analysis that the FTAs in Ladakh is stronger over a period under study compared to foreign tourist arrivals in Kashmir valley. Thus the share of foreign tourist arrivals to Kashmir Valley on an average is low at both the country and state levels. Ladakh has $0.42 \%$, $1.13 \%$ and $0.16 \%$ more share in total tourist arrivals of the state than Kashmir Valley in 2014, 2015 and 2016 respectively. Ladakh has $37.16 \%, 49 \%$, and $40 \%$ more share in total tourist arrivals of the state than Kashmir Valley in 2014, 20152016 respectively.

\section{PROBLEMS IN THE TOURISM INDUSTRY}

Tourism Industry is the most animated tertiary activity and a multi-billion industry. The tourism industry is the outcome of the combined efforts of various sub-industries or sectors which provide tourism related services. Tourism is a collection of activities, service, and industries which deliver a travel experience comprising transportation, accommodation, eating and drinking establishments, retail shops, entertainment, business and other hospitality services provided for individual or group traveling away from home. All these components are tourism products (Sunetra Rody and Biwal 2009). "Tourism does not exist alone it consists of certain components, three of which may consider as basic. These three basic components of tourism are Transport, Locale and accommodation" (Bhatia. A.K. $1978)^{1}$. Consequently, any problem in these sectors would eventually have a negative impact on tourist inflow in the state as well as in Kashmir valley. Realizing the incredible scope of this industry in the growth of an economy, it is necessary to highlight some problems which are bottlenecks in the way of tourist flocks who are eager to visit Kashmir valley in order to give a boost to the tourism industry in the state.

\section{A. Problems of Peace and Security}

The first and foremost problems of any destination across the globe which creates hindrances in the tourist inflow are disruption, violence, and political insurgency etc. The tourism industry is the consequence of peace. Unless and until there is a peace tourism cannot be promoted because it is possible only after tourist feels secure to visit any particular destination. Henderson (2011) has mentioned that International tourists have a negative perception towards a destination because of political instability, security, and safety.

\section{B. Infrastructural Problems}

1. Problems of Accessibility: Tourists look for comfort and hassle-free travel. This refers to the good transport infrastructure (such as roads, flyovers, car terminals and airports etc.) and vehicles to reach the destination and at the destination. Better these facilities more tourists would be attracted to visit the destination and more badly these facilities more setback to tourist inflow at a destination.

2. Problems of Accommodation: It plays a central role in tourism. Travelers and tourist need lodging for rest, sleep, luggage storage, etc. while they are on tour. Tourists look for clean hygienic and well-maintained accommodation with a comfortable bed, clean linen, and sanitary facilities with adequate hot and cold water supply.

3. Problems of Amenities: It refers to the facilities available at the destination help in meeting the needs and wants of tourists. Tourist amenities include food and beverage facilities, drinking water, good communication network, local transport, ATMs, proper garbage and sewage disposal system, medical facilities, electricity etc.

4. Problems of Attractions: Sightseeing is the main reason for undertaking a trip to a particular destination. Attractions are classified basically into four categories entitled as natural attractions, human-made attractions, cultural attractions, and social attractions.

5. Problems of Activities: Most tourist travel to a particular destination for enjoyment and entertainment and like to go for water sports fishing, nature trails etc. Most of the visitors found lack of these facilities at different destinations which make them bored and calamitous.

6. Problem of Worse Relationships: After 1989 tourist arrival decreases sharply and was even closer to zero in 1990-1997 because of warlike situations between Indian and Pakistan our Kashmir issue. Unless and until we don't have better relations with neighboring countries and states tourism cannot be promoted.

7. Problem of Affordability: Tourist should be able to afford the trip in terms of transport cost, accommodation charges, entrance fees attractions, length of stay etc. So it is necessary for tourism marketers to sell their tourism products at reasonable rates.

8. Problems of Marketing: It is market which response to the needs of respondents at a destination. Most of the visitors face the problem of cheating and contamination at marketplaces of this destination. So the marketing mechanism should be transparent, responsible and accountable.

9. Problem and Guides and Escorts: Most of the tourists face the problem of guidance and feel annoyed during their trip. So it is incumbent upon the tourism marketers to provide trained and knowledgeable guides to the visitors.

10. The Problem of Frisking: Most of the visitors face the problem of frisking at different destinations by security persons which ruminate them a sense of threat. So it is incumbent upon the authorities to make the destinations visited by tourists as the places of peace and prosperity.

11. Problems Related Health and Hygiene: The most serious problems at a destination is the problems related to health and hygiene such as bad sewer and waste disposable system, lack of cleanliness, lack of pure 
water supply etc. Therefore it is necessary for both government and private organizations to develop these facilities at different destinations and provide a clean environment for visitors.

12. Problems of Basic Facilities: Problems of basic facilities at destinations relate to electricity, water supply, quality of food, quality of accommodation, sewer and drainage system, security and environment. So it is incumbent upon the government and tourism marketers to provide a better quality of all these basic facilities to the visitors at different destinations.

\section{CONCLUSION}

Tourism is the consequence of peace. If there is peace, tourism will be an automatic boost to our state. It is a known fact that the economy of Jammu and Kashmir is faced with disturbances and armed conflicts from early 1990. Tourist flow shows a decreasing trend in 1989-1990 then again in 2013, 2104, and 2015 and in 2016 because of unrest especially in 2016. Therefore it is obligatory upon governments to provide a conducive environment for tourism. Infrastructural facilities should be developed on public-private partnership mode. Private sectors should be highly encouraged by providing incentives to them in order to develop the hospitality industry and construction of roads. It is incumbent upon the government and tourism marketers to consider the above mentioned multifarious problems as soon as possible in order to boost tourist arrival in the Kashmir valley.

\section{REFERENCES}

[1] Bhat.A.Z. (2013). Tourism Industry and Pilgrimage Tourism in Jammu and Kashmir: Prospects and challenges. Journal of Reseach in Management and Technology, 11.

[2] Mir, L. A. (2014). Economic Evaluation of Indian Tourism Industry An Economic Evaluation of the Indian Tourism Industry. International Journal of Scientific and Research Publications, 4(12).

[3] Mir.H.A. (2014). Impact of Tourism Industry on Economic Development of Jammu and Kashmir. International Journal of Scientific and Engineering Research, 592-598.

[4] Mansour Esmaeil Zaei and Mahin. (2012). The impacts of the tourism industry on the host community. European Journal of Tourism Hospitality and Research, 1(2), 12-21.

[5] Nengroo, H.A \& Bhat.M.G. (2015). Economic Impact of Tourism in Jammu and Kashmir. European Journal of Hospitality and Tourism Research, 5(1), 21-26.

[6] J.Preey, B. (1969). Tourist Spending Pattern in Utah. Montana: Forest Managment Faculty Publications, University of Montana.

[7] Rai, R. A. (2007). .History of Ancient Kashmir. New Dehli: New Academic Publications, New Dehli.

[8] Rathor, K.D, Mir, A.S \& Allie, Y.I. (2014). Role of Tourism in Employment Generation Jammu and Kashmir. Altius Shodu Journal of Managment and Commerce.

[9] Tourism Survey for State of Jammu \& Kashmir, Final Report (May 2014 - June 2015), Ministry of tourism.

[10] Economic survey 2014-2015, 2016-17 and 2017-18. Directorate of Economics \& Statistics, J\&K.

[11] Kumar Altaf (2018). An Economic Analysis of Tourism Sector in Kashmir valley- A Study of Tourist Expenditure pattern. MPhil dissertation submitted to the department of the economics central university of Kashmir.

[12] Bhatia, A. K. (2012). International Tourism Management. New Dehli: Sterling Publishers Private Limited.

[13] Sunetra, Biwal, \& Joshi (2009). Tourism operations and management.Oxford University Press, New Delhi.

[14] Henderson, J. C (2011) Tourism and politics Development, the Philippines. Tourism: An International Multidisciplinary Journal of Tourism, 6(2), 159-173. 